\title{
Геолого-петрологические особенности эклогитов острова Столбиха (Беломорская провинция Фенноскандинавского щита)
}

Максимов О.A.

Институт геологии КарНЦ РАН, Петрозаводск, оlemaximov@mail.ru

\begin{abstract}
Аннотация. Получены новые геологические и петрологические данные о докембрийских эклогитах Гридинского меланжа Беломорской провинции. В строении будины эклогитов на острове Столбиха установлены ранние полосчатые и поздние массивные компоненты, которые, возможно, отражают две стадии эклогитизации пород комплекса. Ранние преобразованные эклогиты-І представлены диопсид-плагиоклазовыми симплектитами-I с реликтами омфацита-I (содержание жадеита 28 \%) и граната (условия образования $\mathrm{T}=750^{\circ} \mathrm{C}$ и $\left.\mathrm{P}=14 \kappa б а р\right)$. Поздние массивные эклогиты-ІІ формируются по ранним эклогитам-I с образованием новой генерации омфацита-II и граната. Этапы метаморфических преобразований массивных пород: 1) эклогитовая фация при $\mathrm{T}=700-800^{\circ} \mathrm{C}$ и $\mathrm{P}=14-17$ кбар; 2) высокобарная гранулитовая фация при $\mathrm{T}=750-850^{\circ} \mathrm{C}$ и $\mathrm{P}=12-15$ кбар; 3) высокобарная амфиболитовая фация при $\mathrm{T}=600-650^{\circ} \mathrm{C}$ и $\mathrm{P}=8-11$ кбар.

Ключевые слова: эклогит; метаморфизм; докембрий; Беломорская провинция; Феносканднавский щит.
\end{abstract}

\section{Geology and petrology of eclogites in the Stolbikha Island (Belomorian Province, Fennoscandian Shield)}

\author{
Maksimov O.A. \\ Institute geologyKarRCRAS, Petrozavodsk, olemaximov@mail.ru
}

\begin{abstract}
New geological and petrological data on Precambrian eclogites from the Gridino mélange, Belomorian Province, were obtained. An eclogite boudin from Stolbikha Island was found to comprise early banded and late massive units that seem to reflect two rock eclogitization stages of the complex. Early metamorphosed eclogites-I occur as diopside-plagioclase symplectites-I with relics of omphacite-I (jadeite content $28 \%$ ) and garnet (conditions of formation: $\mathrm{T}=750^{\circ} \mathrm{C}$ and $\mathrm{P}=14 \mathrm{kbar}$ ). Late massive eclogites-II were derived after early eclogites-I, forming a new generation of omphacite-II and garnet. Metamorphic alteration stages of massive rocks: 1) eclogite facies at $\mathrm{T}=700-800^{\circ} \mathrm{C}$ and $\left.\mathrm{P}=14-17 \mathrm{kbar} ; 2\right)$ high-pressure granulite facies at $\mathrm{T}=750-850^{\circ} \mathrm{C}$ and $\mathrm{P}=12-15 \mathrm{kbar}$; 3 ) highpressure amphibolites facies at $\mathrm{T}=600-650^{\circ} \mathrm{C}$ and $\mathrm{P}=8-11 \mathrm{kbar}$.
\end{abstract}

Key words: eclogite; metamorphism; Precambrian; Belomorian Province; Fennoscandian Shield.

В ходе изучения Беломорской провинции Фенноскандинавского щита были обнаружены эклогиты и продукты их ретроградного преобразования (Володичев и др., 2004, Минц и др., 2010; Щипанский и др., 2012 и др.). В районе с. Гридино установлены два эпизода эклогитового метаморфизма: архейский в телах основных пород и палеопротерозойский в дайках габброноритов (Володичев и др., 2004). Эклогиты, в основной массе ретроградно преобразованные, являются преобладающей составляющей обломочного компонента Гридинского меланжа и крайне важным объектом для понимания характера геодинамических процессов в раннем докембрии. Несмотря на длительную историю изучения этих пород, у исследователей нет единого мнения о времени и кратности проявления эклогитового метаморфизма в этом регионе. Геологические и геохронологические данные свидетельствуют о высокобарном метаморфическом событии в архейское время (Володичев и др., 2004; Li et al., 2015). Однако в последнее время многие ученые изотопно-геохимическими и минералогическими данными обосновывают исключительно палеопротерозойский возраст, около 1.9 млрд. лет всех эклогитов Гридинской структуры (Yu et al., 2017; Brown, Johnson, 2018). Следует также привести точку зрения о том, что возраст эклогитового метаморфизма, установленного в эклогитизированных габброидах, в рассматриваемом районе - 2.82-2.78 млрд. лет (Dokukina, Konilov, 2011).

В данной статье представлены новые геологические и петрологические данные об эклогитах Гридинского меланжа Беломорской провинции. Детально изучено, с акцентом на внутреннюю неоднородность, тело эклогитов в юго-восточной части острова Столбиха, которое ранее было описа- 
но в статьях (Володичев и др., 2004; Li et al., 2015). Вмещающие породы представлены мигматизрованными биотитовыми гнейсами ( \pm гранат, амфибол, диопсид).

В строении будины острова Столбиха установлены преобразованные полосчатые и массивные эклогиты. Прослеживается плавный переход от полосчатых к массивным эклогитам с постепенным изменением минерального состава пород.

Полосчатые преобразованные эклогиты имеют полосчатую и сланцеватую текстуру с чередованием меланократовых амфиболизированных зон с массивными симплектитами (А) и лейкократовых светло-зеленых прослоев с ориентированными симплектитами (Б).

(A) Меланократовые участки породы представлены Grt'-Bt-Cpx-Amp-Pl-Qz \pm Ttn, Rt минеральной ассоциацией. Характерной особенностью породы является наличие массивных диопсидплагиоклазовых симплектитов и повышенное содержание вторичного амфибола.

Клинопироксен представлен в виде дактилитовых срастаний с плагиоклазом в симплектитах (сод. Jd 4-10 \%, An 25-30 \%) и отдельных более крупных не зональных зерен (Jd 6-11 \%). Наиболее высокое содержание жадеита обнаружено в реликте омфацита (Jd 28 \%) из включения в центральной части граната. Для оценки первичного состава симплектитов из матрикса породы сделаны площадные определения химического состава наиболее массивных биминеральных Di-Pl срастаний, исключая участки с амфиболом. Химический состав исследованных областей соответствует омфациту с содержанием жадеитого компонета от 20 до $28 \%$.

Гранат имеет идиоморфную или гипидиоморфную вытянутую форму, содержит включения клинопироксена, плагиоклаза, цоизита, амфибола и кварца. Внешняя граница граната окаймляется плагиоклазом или амфиболом. Установлены следующие вариации состава граната: пиропа 14-21 \%, альмандина 37-44 \%, гроссуляра 28-34 \%.

Амфибол представлен самостоятельными крупными зернами либо каймами обрастания вокруг симплектитов. Он относятся к кальциевой серии, в основном это паргасит, а также чермакит и магнезиальная роговая обманка.

Среди зерен плагиоклаза встречаются зональные кристаллы с высоким содержанием анортитового компонента до 90 \%, в центральной части которых часто встречаются таблитчатые зерна цоизита или эпидота. Среднее содержание анортитового компонента в плагиоклазе из матрикса породы колеблется от 20 до $50 \%$.

(Б) Лейкократовые породы обладают близким минеральным составом Grt-Cpx-Amp-PlQz \pm Ttn, Rt. От меланократовых участков отличаются хорошо выраженной плоскостной текстурой, образованной ориентированными деформированными сростками клинопироксена и плагиоклаза. В породе содержится меньше амфибола, а для клинопироксена характерна удлиненная таблитчатая форма зерен (Jd 2-11 \%). В участках породы с высоким содержанием клинопироксена сохраняются симплектитовые клинопироксен-плагиоклазовые срастания (Jd 2-8 \%). Оценки первичного химического состава симплектитов по площади отвечают омфациту (Jd около 20 \%). Остальные минералы породы имеют схожие характеристики с зоной (А).

Последовательность смены минеральных ассоциаций и РТ-условия их образования для полосчатых преобразованных эклогитов выглядят следующим образом:

1) Ранний Grt-Omp минеральный парагенезис отражает максимальные условия метаморфизма с $\mathrm{T}=750^{\circ} \mathrm{C}$ и $\mathrm{P}=14$ кбар, что соответствует эклогитовой фации в пограничной области с высокобарной гранулитовой фацией метаморфизма (температуры рассчитана с помощью биминерального Cpx-Grt геотермометра (Powell, 1985), давление по содержанию Jd в Cpx (Holland, 1980));

2) Минеральная ассоциация Grt-Cpx-Amph-Bt-Pl-Qz образовалась при снижении давления до 11-14 кбар и некотором увеличении температуры $750-900^{\circ} \mathrm{C}$, то есть в условиях декомпрессионного ретроградного преобразования в области высокобарной гранулитовой фации (здесь и далее в тек-

\footnotetext{
${ }^{1}$ Сокращения минералов приняты по (Kretz, 1983). Кроме того, Jd - содержание жадеитового компонента в клинопироксене, An - содержание анортитового компонента в плагиоклазе.
} 
сте давления и температуры рассчитаны методом TWEEQU (Berman, 1991) с использованием программ TWQ_Comb и TWQ_View Д.В. Доливо-Добровольского).

В массивных эклогитах обнаружены реликтовые линзовидные включения полосчатых интенсивно амфиболизированных эклогитов (рис. 1 a), состоящие на $90 \%$ из амфибола с редкими зернами омфацита и граната. От вмещающих эклогитов эти участки отделяет граница с резким переходом от амфибола к омфацит-гранатовому минеральному парагенезису. На контакте с вмещающими эклогитами зерна омфацита содержат включения амфибола. Амфиболы из включений в омфаците и в линзе амфиболитов имеют близкий состав.
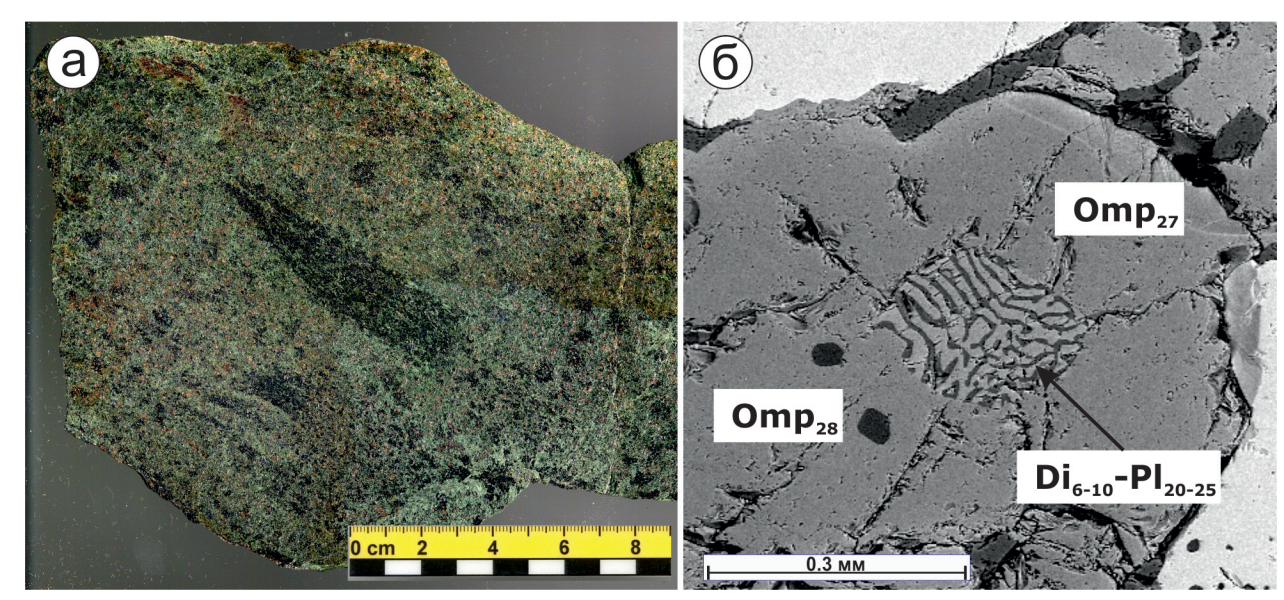

Рис. 1. (а) - массивные эклогиты с реликтовой линзой амфиболитов; (б) - включения дактилитовых Di-Pl симплектитов в монокристалле Оmp, изображение в обратно-рассеянных электронах.

Fig. 1. (a) - massive eclogites with relict amphibolite lens; (б) - dactylitic Di-Pl symplectite inclusions in single crystal Omp, backscattered electron image.

Массивные эклогиты преимущественно состоят из гранат-омфацитового минерального парагенезиса. Второстепенные минералы представлены амфиболом, плагиоклазом, кварцем, рутилом, цоизитом, эпидотом.

Клинопироксен представлен крупными зональными кристаллами омфацита (Jd до 35 \%) в матриксе породы. Для данной группы омфацита характерно резкое снижение жадеитового ком-

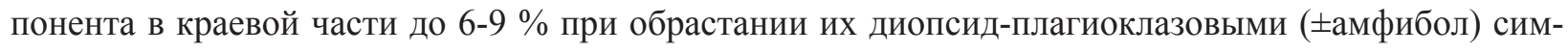
плектитами. Среди симплектитовых срастаний в матриксе породы можно выделить два морфотипа: «грубые» Di-Pl (Jd 14-19 \%, An 19-24 \%) отражают раннюю стадию декомпрессии пород и «тонкие» Di-Pl (Jd 6-12 \%, An 21-24 \%) - поздние симплектиты. В некоторых монокристаллах омфацита в центральной части содержатся включения диопсид-плагиоклазовых симплектитов (Jd 4-16 \%, An 23-30 \%) ранней генерации (рис. 1 б). В данных включениях прослеживается резкий секущий контакт включений симплектитов с более поздним омфацитом.

В крупных зональных кристаллах граната изменяется состав минеральных включений от центра к краю. Центральная часть зерна обогащена мелкими включениями цоизита, омфацита, кварца и рутила. В краевой зоне граната располагаются более крупные включения амфибола, плагиоклаза, клинопироксена и кварца. От граната из полосчатых эклогитов отличаются более высокими содержанием пиропа 21-27 \% и низким гроссуляром 23-29 \%, альмандина 36-45 \%. Изменение химического состава граната от центра к краю меняется незначительно.

Амфибол наиболее широко представлен в матриксе породы, где он замещает клинопироксен и образует срастания с плагиоклазом. Другая разновидность амфибола распространена в качестве включений в гранате и отличается постоянным содержанием хлора. По химическому составу амфибол относится к паргаситу, реже чермакиту, эдениту и магнезиальной роговой обманке.

Последовательность смены минеральных ассоциаций и РТ-условия их образования для массивных эклогитов: 
1) Описанные включения Di-P1 симплектитов в монокристаллах омфацита, вероятно, являются ранней ассоциацией ретроградного преобразования полосчатых эклогитов-I;

2) Следующий этап преобразования пород связан с формированием Grt-Omp минерального парагенезиса и включений Zo, Qz, Rt, Cpx в центральной части граната при $\mathrm{T}=700-800^{\circ} \mathrm{C}$ и $\mathrm{P}=14-17$ кбар - эклогитовый метаморфизм-II;

3) Последующие этапы отражают ретроградные изменения породы. Происходит последовательное преобразование омфацита с формированием «грубых», а затем «тонких» Di-Pl симплектитовII и парагенетичных им граната и амфибола в каймах обрастания. Данный этап соответствует высокобарной гранулитовой и амфиболитовой фациям с $\mathrm{T}=750-850^{\circ} \mathrm{C}$ и $\mathrm{P}=12-15$ кбар;

4) Наиболее поздний этап прослеживается в приконтактовой области с вмещающими гнейсами. Для этой области характерно образование породы амфиболового состава с редкими находками клинопироксена, резко резорбированными кристаллами граната и повышенным содержанием новообразованного биотита. Образование этих минералов происходило при $\mathrm{T}=600-650^{\circ} \mathrm{C}$ и $\mathrm{P}=8-11$ кбар в области высокобарной амфиболитовой фации.

Таким образом, по геологическим и петрологическим данным в будине острова Столбиха отчетливо выделяются две составляющие: преобразованные полосчатые и массивные эклогиты. Массивные эклогиты содержат включение линзы, сложенной амфиболом с реликтами омфацита и граната ранней генерации. В обрамлении линзы образуются омфациты с включениями амфибола сопоставимого по составу с амфиболами из линзы. Некоторые монокристаллы омфацита-II выступают в качестве минерала-контейнера и содержат включения Di-Pl симплектитов, которые могут быть реликтами преобразованных полосчатых эклогитов. Эти данные используются в качестве возможных признаков более позднего образования массивных эклогитов относительно преобразованных полосчатых эклогитов.

Автор выражает благодарность О.И. Володичеву (Институт геологии КарНЦ РАН) за помощь в работе над статьей.

Работа является вкладом в исследования по теме АААА-А18-118020290085 и частично поддержана из средств гранта РФФИ (16-05-01031).

\section{Литература}

1. Володичев О.И., Слабунов А.И., Бибикова Е.В., Конилов А.Н., Кузенко Т.И. Архейские эклогиты Беломорского подвижного пояса (Балтийский щит) // Петрология. 2004. Т. 12. № 6. С. 609-631.

2. Минц М.В., Конилов А.Н., Докукина К.А. и др. Беломорская эклогитовая провинция: уникальные свидетельства мезо-неоархейской субдукции и коллизии // Доклады АН. 2010. Т. 434. № 6. С. 776-781.

3. Щипанский А.А., Ходоревская Л.И., Слабунов А.И. Геохимия и изотопный возраст эклогитов Беломорского пояса (Кольский полуостров): свидетельства о субдуцировавшей архейской океанической коре // Геология и геофизика. 2012. Т. 53. № 3. С. 341-364.

4. Berman R.G. Thermobarometry using multi-equilibrium calculations: a new technique, with petrological applications; in, Quantitative methods in petrology: an issue in honor of Hugh J. Greenwood; Eds. Gordon, T M; Martin, R F. Canadian Mineralogist. 1991. V. 29. P. 833-855.

5. Brown M., Johnson T. Secular change in metamorphism and the onset of global plate tectonics // American Mineralogist. 2018. V. 103. P. 181-196.

6. Dokukina K.A., Konilov A.N. Metamorphic evolution of the Gridino mafic dyke swarm (Belomorian eclogite province, Russia). In: Ultrahigh-Pressure Metamorphism. 5 Years After the Discovery of Coesite and Diamond (eds Dobrzhinetskaya, L.F., Faryad, S.W., \& Wallis, S.). 2011. P. 579-621.

7. Holland T.J.B. The reaction albite=jadeite+quartz determined experimentally in the range 600-1200 grad. C // Amer. Mineral. 1980. V. 65 P. 129-134.

8. Kretz R. Symbols for rock-forming mineral / Amer. Miner. 1983 V. 68. P. 277-279.

9. Li X. L., Zhang L. F., Wei C. J., \& Slabunov A. I. Metamorphic PT path and zircon U-Pb dating of Archean eclogite association in Gridino complex, Belomorian province, Russia // Precambrian Research. 2015. V. 268. P. 74-96.

10. Powell R. Regression diagnostics and robust regression in geothermometer/ geobarometer calibration: the garnetclinopyroxene geothermometer revised // J. Metamorph. Geol. 1985. V. 3. N 3. P. 231-243.

11. Yu H.L., Zhang L.F., Wei C.J., Li X.L., Guo J.H. Age and P-T Conditions of the Gridino eclogite in the Belomorian Province, Russia // Journal of Metamorphic Geology. 2017. V. 35. P. 855-869. 